\title{
Cinema e Política: a representação do jornalismo e do marketing político no cinema brasileiro
}




\section{Resumo}

O cinema brasileiro dos anos noventa busca diagnosticar as rápidas mudanças ocorridas no campo da comunicação nesse período. $\mathrm{O}$ filme Doces Poderes, de Lúcia Murat, mostra como o jornalismo brasileiro, quando submetido ao marketing político e à publicidade, perde seu papel de fonte primária de informação e abre espaço para a "notícia enquanto produto". Ainda que o filme aparentemente vise lançar um olhar crítico sobre a situação do jornalismo dos anos noventa, a linguagem cinemática e a estrutura narrativa nele usadas solapam seu intento, revelando assim as fragilidades e limitações do cinema brasileiro de viés político.

\section{Palavras-chave}

cinema, jornalismo, marketing

\section{Abstract}

Brazilian movies in the 1990's seek to provide a diagnosis of the rapid changes occurred in the field of communications during that period. The film Doces Poderes (Sweet Powers), by Lúcia Murat, shows how Brazilian journalism, when subjected to political marketing and advertising, loses its power as a primary source of information and gives room to what is know as "news as product". Although Murat's film purports to be a critical reading of the state of journalism in the 90 's, its cinematic language and narrative structure undermine its intent, revealing instead the frailties and limitations of the Brazilian cinema of political slant.

\section{Key words}

journalism, movies, political marketing, advertising 


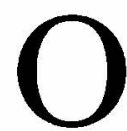

jornalista brasileiro vive uma nova fase em que disputa espaço na crescente indústria da comunicação e, ao mesmo tempo, é subserviente, na maioria dos casos, ao poder das empresas, do Estado “ coercitivo como no filme Lúcio Flávio, o passageiro da agonia (1976), de Hector Babenco \% e às correntes ideológicas. Como o cinema brasileiro representa o jornalista nessa nova fase? De que forma o filme Doces poderes (1996), de Lúcia Murat, apresenta o jornalista de televisão submetido ao poder do marketing e da publicidade?

O jornalista de Babenco avaliza tanto os autênticos (o bem) como os hipócritas (o mal) porque suas possibilidades de argumentação, questionamento e decisão estão reduzidos por um contex to político desfavorável, além da estrutura narrativa que acolhe, sem questionar, tanta "neutralidade". Nos filmes de jornalista da década de 1990, o poder do jornalista é circunscrito a poucos profissionais - principalmente os da televisão -, pois a autonomia perde espaço, entre outros, para a exuberância da objetividade representada inclusive nos filmes.

Quando os policiais federais saem da sala onde está se desenrolando a coletiva, os jornalistas não dizem nada. Lúcio Flávio denúncia o Esquadrão da Morte, mas o poder simbólico do jornalista está ancorado na polícia e no Estado, e não em sua capacidade opinativa. Seu recurso é a objetividade opaca e o surrado "ouvir os dois lados" sem a necessária investigação da informação e a mínima reflexão.

Obra de referência em relação ao jornalismo e adotada nas universidades brasileiras, Sobre a televisão de Bourdieu (1997) faz uma análise do jornalismo e do jomalista francês. Ojornalismo europeu 
rivaliza em abundância com o americano, do qual o jornalismo brasileiro copia e partilha procedimentos e conceitos. Há, na indústria cultural francesa, a possibilidade de identidades mínimas para o jornalista. No entanto, o campo jornalístico brasileiro carece de maior pujança intelectual, uma estrutura econômica menos coercitiva e independência estratégica do Estado para fazer sobressair o jornalista que irá obter o mínimo de espaço na indústria da comunicação.

O filme de Lúcia Murat, Doces poderes, significativo por representar o jornalista de televisão envolvido no centro do embate entre mídia e política, provoca indagações a respeito do papel e autonomia do campo jornalístico na virada do século XX no Brasil. No roteiro, em sua última versão antes da filmagem, a cineasta justifica seu projeto e apresenta a sinopse do filme. ${ }^{1} \mathrm{Na}$ análise, antes de adentrar ao universo filmico, abordo os dois textos (justificativa e sinopse) que são cotejados com o filme.

\section{A justificativa do projeto:}

Vivemos num mundo onde à razão cínica não se contrapõe mais a razão utópica. O filme Doces Poderes coloca a olho nu esta questão, de vários pontos de vista: o da midia, o do poder político e a ótica individual dos profissionais da comunicação. Sua importância está em mostrar como esta questão se dá concretamente no Brasil, um país onde uma democracia recente convive com um capitalismo perverso. Desnudar a forma como o poder político se estabelece, mostrando todas as forças em jogo numa eleição é de extrema importância para que se possa apreender o pais em que vivemos. As altas verbas destinadas às campanhas eleitorais tornaram natural que publicitários, redatores, repórteres, cinegrafistas e diretores aderissem a esse

1. O roteiro com a apresentação (usada tanto como justificativa no projeto para a captação de recursos quanto na divulgação do filme) e a sinopse foram formecidos pelo escritório da cineasta Lucia Murat, com autorização em setembro de 2002 . A versão aqui referida é a que orientou a realização do filme; lembrando, desde já, que praticamente nenhum filme segue totalmente as marcações e diálogos apontados no roteiro. 
mercado sem que houvesse qualquer critério, a não ser o financeiro, para a escolha dos candidatos aos quais iriam servir enquanto profissionais. Premidos na luta pela sobrevivência, perdidos entre os sonhos que acabaram, a questão ética parece Ter se tornado algo do passado. A esquizofrenia e a selvageria destas relações estão à mostra neste filme.

Para o espectador, esta é uma oportunidade de se emocionar, pensar e refletir sobre a realidade brasileira, sem maniqueismos. Podres poderes ou doces poderes? Neste confuso fim de século, o filme pergunta: como sobreviver a todas essas contradições, se não existe mais um mito no fim do túnel? Doces Poderes se insere na linha dos filmes que pretendem restabelecer uma relação com o espectador brasileiro, respeitando-o como alguém que pode e deve ser crítico. $E$ apesar de desnudar relações de poder existentes no nosso país, trata de questões que atingem o mundo todo: a monetarização das relações humanas, o novo papel da midia, a crise da ética. Por isto, o filme, a exemplo do último trabalho da diretora Lúcia Murat (Que bom te ver viva, 1989), tem todas as condições de atingir também o mercado internacional. Se falar, com vigor e coragem, da nossa aldeia é falar para o mundo, Doces Poderes é um filme do mundo.

Neste texto, utilizado para captar financiamento e para apresentar o projeto à mídia, a cineasta esboça sua visão de mundo e os motivos pelos quais pretende refletir sobre o jornalismo e a política. De antemão estabelece uma oposição entre uma "razão cínica"2 e

2. Uma referência para refletir sobre a ascensão da racionalização que remete ao quadro estrutural apontado pela cineasta, encontra-se em Weber (1946). A ascensão do "cinismo" está alicerçada em parte na racionalização, que desloca a orientação tradicional de valores racionais para a ação puramente instrumental e desenvolve progressivamente meios tecnicamente racionais de controle sobre o homem e a natureza. No campo da ética, o cinismo é "o desprezo pelas convenções sociais, pela opinião pública e mesmo pela moral comumente admitida, seja nos atos, seja na expressão das opiniōes" (Lalande, 1999, p. 162). 
uma "razão utópica". Em sua visão, o mundo da mídia e da política está cindido entre os cínicos e alguns ainda autênticos, como a protagonista do filme. Não há meio termo na interpenetração do campo jornalístico e do campo político onde uma "democracia recente convive com um capitalismo perverso". Seu objetivo é desnudar a forma de fazer política incrementada pelas práticas de comunicação. Nesse processo, põe a nu os mecanismos que fazem os profissionais da comunicação, principalmente os jornalistas, aderir maciçamente a um mercado novo que tende a submeter o campo jornalístico às normas do marketing, da política e das relações públicas. Seu projeto reafirma a oposição cinismo e autenticidade ao mostrar os jornalistas "perdidos entre os sonhos que acabaram" e a luta pela sobrevivência.

De fato, os anos 90 confirmam a trajetória de ascensão da indústria cultural, embrionária nos anos 60. Renato Ortiz (1988), ao afirmar que, "espremida entre o pensamento conservador e a questão nacional, a modernização foi assumida como um valor em si, sem ser questionada", esquece de mencionar os diagnósticos que o cinema brasileiro vem realizando desde o eclodir dos primeiros filmes do Cinema Novo. Pode-se avaliar que, quem fez diagnósticos e ponderações, entre outras sanções, foi posto à margem do processo na caminhada para a consolidação de uma indústria cultural. Dessa forma, o cinema e o jornalismo foram os campos que mais se ressentiram por realizar, entre outras coisas, o balanço do processo de "industrialização da cultura", - além de serem obrigados a se submeter à crescente indústria da televisão (o cinema), e ao predomínio do marketing e da publicidade (o do jornalismo). ${ }^{3}$

Visando compreender a trajetória do jornalista no cinema brasileiro, Lúcio Flávio (1976) demonstra, a partir dos anos 70, o fastio em relação a uma representação que não seja acomodada a

3. Bourdieu (1997) insiste em responsabilizar exageradamente o profissional. E também o motivo para considerar que sua leitura, no Brasil, é feita de forma apressada, sem levar em consideração o mercado da comunicação e a redução do espaço de autonomia para o jornalista. Para refletir com Bourdieu sobre o campo jornalistico, levando em consideração a realidade do jornalista brasileiro, ver $O$ segredo da pirâmide (Genro Filho, 1987), O papel do jornal (Dines, 1986) e Decidindo o que é notícia (Pereira Jr, 2001). 
uma visão apaziguadora, para não dizer conciliadora, com a utilização de uma narrativa de base griffithiana (narrativa clássica americana). A dificuldade contextual (entenda-se política) direcionou a opção de linguagem de Hector Babenco, mas para Lúcia Murat, os óbices não são os mesmos. Em Doces poderes (1996) os entraves de ordem política já não existem, porém o diagnóstico mostra-se frágil em face da submissão do cinema brasileiro a uma nova ordem econômica. Por isso, na apresentação do projeto fica evidente a ambigüidade: o filme quer fazer a crítica a um estado de coisas e, ao mesmo tempo, ser sedutor para o mercado: "Esta é uma oportunidade de se emocionar, pensar e refletir sobre a realidade brasileira, sem maniqueísmos. (...) O filme, a exemplo do último trabalho da diretora Lúcia Murat, tem todas as condições de atingir o mercado internacional. Se falar, com vigor e coragem da nossa aldeia é falar para o mundo, Doces poderes é um filme do mundo."

É possível realizar filmes críticos dentro da estrutura comunicacional de mercado. A questão já demonstrada na apresentação do projeto do filme é a escolha e o manuseio da linguagem para atingir o objetivo, pois se lê: "para o espectador, esta é uma oportunidade de se emocionar, pensar e refletir sobre a realidade brasileira, sem maniqueísmos". O que significa isso? A origem do vocábulo remete à "concepção filosófica que admite dois princípios cósmicos coeternos, um do bem, o outro do mal" (Lalande, 1999, p.643). A cineasta procura o caminho inverso e o maniqueísmo do filme é plausível. Basta observar, na linguagem cinematográfica utilizada, o quanto afeta o diagnóstico do jornalismo e da política.

O manejo das ferramentas de linguagem levam o cineasta a operar escolhas. Há cineastas que manejam, com a contribuição do contexto cultural, social e político, a linguagem cinematográfica para achados brilhantes no intuito de realçar ou enfatizar determinada mensagem. Dois filmes demonstram essa premissa: Boca de ouro (1962) e Brasil ano 2000 (1969). Aliás, o primeiro pode ser cotejado diretamente com Doces poderes, pois utiliza a linguagem clássica e consegue realizar uma profunda abordagem crítica do jornalismo. Dois nomes manejavam a linguagem, Nelson Rodrigues e Nelson Pereira, e a conjuntura da época favorecia a ironia com a linguagem 
jornalística. Mesmo com os defeitos, Walter Lima Jr faz uma leitura da prática jornalística favorecida pela aura tropicalista que lhe assegurava influências para exercer a criatividade e a critica em Brasil ano 2000.

Lúcia Murat, nos anos 90, estabelece metas pretensiosas para dar conta criticamente dos campos da política e do jornalismo. As intenções ficam ainda mais claras na sinopse do filme. A inspiração histórica para o enredo é a campanha presidencial de 1989, quando concorreram Luiz Inácio Lula da Silva (PT) e Fernando Collor de Melo (PRN). No dia 15 de dezembro daquele ano, antevéspera do segundo turno, a TV Globo levou ao ar a edição do debate entre os candidatos no seu telejornal mais importante. Há indícios de que houve manipulação da edição, favorecendo o candidato Fernando Collor. ${ }^{4}$ $\mathrm{O}$ caso suscitou diversas indagações sobre a ética no jornalismo e, junto com a cobertura dos jornais diários, dois exemplos do balanço do episódio e seus desdobramentos são o filme de Lúcia Murat e o livro de Mário Sérgio Conti, Noticias do Planalto..

\section{A sinopse do filme:}

Jornalista chega a Brasilia para assumir, durante o periodo eleitoral, a chefia da sucursal da principal rede de TV do país. $O$ antigo diretor está indo chefiar a campanha de um jovem candidato a governador, apoiado por politicos conservadores, que utiliza um discurso entre o populista e o moderno. Metade dos profissionais está se retirando, sob as mais variadas desculpas, para ganhar salários milionários nos mais diferentes estados (Rondônia, Pará, etc) fazendo campanha politica para todos os tipos de candidatos, sem qualquer critério, politico ou ético. Esses profissionais vão surgir, ao longo de todo o filme, em depoimentos nas ilhas de edição. Os mais variados

4. Sobre o episodio, Conti (1999) traz à tona, sob criticas (Silva, 1999, p.4), detaIhes que incriminam a emissora e os jornalistas responsáveis pela edição. $O$ caso colocou a emissora novamente como suspeita de colaborar com os governos em vigor. 
discursos - desde a crise econômica até a falta de perspectiva desse final de século - justificam suas opções. Através destes discursos, o filme mostra o desenvolvimento das campanhas e os conflitos vividos por estes personagens. A jornalista, por sua vez, está em crise diante do que se passa em sua profissão. Na redação, destaca-se o novo chefe de reportagem, um rapaz eficiente, de outra geração, preocupado acima de tudo com sua carreira na televisão. A jornalista encontra um deputado ex-militante de esquerda, amor de adolescente, casado, com uma vida tradicional, com quem volta a estabelecer uma relação. Forma-se, então, um triângulo amoroso envolvendo estes três personagens, onde, além das diferenças de idade $e$ formação, questões como o poder da mídia e o papel do jornalismo no mundo de hoje vão colocá-los em cheque. Todos os personagens vão se deparar, durante o filme, com situações ambíguas e eticamente discutiveis. Não existe mais preto e branco e todos se vêem diante dessa estranha realidade cinza. $O$ deputado, para poder emplacar seu partido, faz frente em outros estados com candidatos à direita. A jornalista vê seu trabalho manipulado pela direção da emissora. E a própria campanha em Brasilia vai num crescendo de apelações e utilizações pessoais. A reação a estas manipulações e a todas estas contingências, entremeada por reencontros e desencontros afetivos, é a história deste filme.

A primeira pretensão explícita é mostrar a ancoragem do jornalismo ao marketing. A jornalista Bia (Marisa Orth), a heroína, chega a Brasília e vai substituir um colega que se afastou para chefiar a assessoria de comunicação de um candidato populista e conservador, numa alusão ao ex-presidente Fernando Collor. Em seguida, apresenta os efeitos dessa ancoragem submissa, ao apresentar o pragmatismo dos jornalistas que abandonaram as antigas utopias e compromissos éticos da profissão: aqueles que vão participar de campanhas políticas ou coordená-las em várias regiões do Brasil e também os carreiristas 
que pouco se importam com a situação e se submetem aos "novos tempos". A pretensão se fecha na narrativa com o diagnóstico da esquerda brasileira e seu pragmatismo, ao abandonar antigos ideais para se conformar à atual conjuntura [Realizado em 1996, o filme "antecipa" os dilemas da esquerda brasileira com a ascensão do PT, em 2003, à Presidência da República]. O personagem Chico (Antônio Fagundes) é deputado e trava embate com a heroína de quem é amante. Ela o denomina de Poliana, ele a chama de inglesa romântica: "O deputado, para poder emplacar seu partido [alusão a nova estratégia conciliatória do PT], faz frente em outros estados com candidatos à direita. A jornalista vê seu trabalho manipulado pela direção da emissora (...) e está em crise diante do que se passa em sua profissão." (apresentação do projeto)

O filme empreende uma análise da presença do marketing no jornalismo e na política na tentativa de representar a submissão dos segundos às regras do primeiro. Na pesquisa sobre o jornalista, Alzira Abreu anota a nova configuração do jornalismo na comunicação:

$A$ introdução do marketing, e das pesquisas de mercado a ele associadas, veio tentar adequar o meio de comunicação, visto como um "produto", ao público consumidor leitor, ouvinte ou telespectador, visto como "cliente". A partir das características desse público, de suas expectativas, de seus gostos e valores, passou-se a definir o conteúdo, a linguagem e a apresentação daquilo que lhe era oferecido. Não foi só o público que passou a influir diretamente sobre os meios de comunicação. Também as empresas de publicidade procuraram induzir as empresas jornalisticas a se tornar meios mais atraentes e sedutores de divulgação, para os produtos anunciados (Abreu, 2002, p. 28/29)

A pesquisadora da Fundação Getúlio Vargas, Alzira Abreu, coordenou o projeto "Brasil em transição: um balanço do final do século XX”.Esse projeto realizou um diagnóstico da imprensa e dos 
jornalistas entre os anos 70 e 2000 . Antes de dissecar o filme vale registrar algumas conclusões da pesquisa com o intuito de cotejar depois com a narrativa. A primeira observação da pesquisa é quanto ao deslocamento do estatuto do leitor para o de cliente. A mudança nas empresas de comunicação visa a adequação da notícia a embalagem sedutora proporcionada pelo marketing. A notícia não sofrerá mais somente as influências das ações pessoal, social, ideológica, cultural e histórica (Sousa, 2002), mas fundamentalmente será filtrada e monitorada pelo marketing. O leitor passa a ser cortejado como um cliente. A antiga relação muda para acompanhar o advento da tecnologia (velocidade) e o novo modelo cultural que enseja uma outra maneira de trabalhar a informação. Para isso, é introduzida a pesquisa de opinião, instrumento que vai conduzir o marketing, ou seja, a maneira de vender a notícia. Essas pesquisas, segundo Abreu (2002, p. 29), "se tornaram fundamentais para enfrentar a competição, além de apontar os assuntos que despertam mais interesse no leitor e levam à introdução de inovações na forma da apresentação das matérias. Criou-se, portanto, uma relação estreita entre as exigências mercadológicas e as redações". Exigências marcadas sobretudo pela velocidade, que já é fator de extrema pressão no cotidiano da profissão.

No filme It happened tomorrow (O tempo é uma ilusão), de René Clair, analisado por Stela Senra, o tempo é tratado como o objeto de intensa investigação, tanto no seu ciclo natural como na vida do jornalista. O surgimento das novas tecnologias no final do século 19, transforma as relações de trabalho e impõe uma nova rotina e novas maneiras de se adequar ao "tempo da velocidade":

Com efeito, a modificação dos ritmos de trabalho e da vida cotidiana em virtude do aporte tecnológico e da industrialização do final do século, a substituição do trabalho artesanal pelo trabalho coletivo, e, enfim, a existência do individuo isolado, introduzem uma transformação da experiência temporal e novos padrões de utilização do tempo. É com esta ruptura da circularidade temporal que o passado perde seu caráter 
de referência e continuidade, e o presente passa a emergir como novidade, com o poder crescente da atualidade substituindo a memória e a experiência passadas (Senra, 1997, p. 90)

O jornalismo de televisão é um dos segmentos do campo da comunicação que mais vai sofrer com a obsessão pela "atualidade" imposta pela velocidade. Se o jornalismo trabalha com a novidade, $o$ fato do momento, cerne da atividade, a pressão pelo "presente a qualquer preço" vai acarretar profundas mudanças e o jornalista terá que lidar o com a falta de tempo para a mínima reflexão na construção da notícia. Insistir na idéia da perda da identidade mínima para o jornalista significa se debruçar exatamente sobre a questão do tempo. Se a profissão já é naturalmente refém do tempo, o advento da aceleração do mundo moderno dificulta a possibilidade da confecção da notícia com mais reflexão. Dai surge a objetividade como modelo ideológico para tentar superar a aceleração do tempo e não deixar o jornalista ser surpreendido pelas vicissitudes do novo modelo. Uma vez que a linha de montagem da notícia reproduz a racionalização, a objetividade, aliada a idéia de profissionalismo, vai ser colocada sempre como a solução para a ausência de opinião. Não é por acaso que os jornalistas vão usar exageradamente a objetividade no telejornalismo. $\mathrm{Bia}$, num determinado momento do filme, corre para editar uma matéria que o jovem jornalista carreirista pressupõe não ser possível colocar no ar. Sua determinação é coerente com seus anos de experiência com a escassez de tempo. Finalmente, a matéria vai ao ar e Bia consagra sua intencionalidade objetiva.

A nova forma de utilizar o tempo e a conseqüente velocidade, juntamente com a pesquisa de opinião coordenada pelo marketing, expõe a idéia, para o jornalista, de que o público precisa se informar mais rápido. Não há muito tempo no jornalismo para a elaboração e as notícias passam a proporcionar um panorama velocíssimo do mundo (principalmente no jornalismo On line). Para o jornalista, o único paradigma da profissão passa a ser a "informação que não se estoca" (Dantas, 1996) e deve ser alçada à condição exclusiva de produto para o antigo leitor, hoje cliente. Daí imperar a lógica da velocidade: 
Qualidade é identificada com a rapidez na transmissão da informação. Coerentemente, as próprias condições de trabalho - que, como se sabe, são determinantes na produção do discurso - ficam subordinadas a essa "lógica da velocidade", apresentada como um dado da realidade, como se fosse dotada de uma dinâmica própria, e não como resultado da rotina industrial (Moretzsohn, 2002, p.12)

A lógica da velocidade obriga os jornalistas a produzir textos curtos, telegráficos e eles, como anota Abreu (2002, p. 30), "passam a se preocupar com o uso da imagem. Proliferam as colunas de notas curtas, que têm um número elevado de leitores [a velocidade impõe também ao leitor um compromisso pequeno com a aferição da qualidade da notícia]. Passou-se a utilizar com maior intensidade recursos gráficos como tabelas, quadros e mapas. $\mathrm{Na}$ transmissão da notícia, foi adotado um padrão de texto impessoal, seco, descritivo, rigoroso no sentido de não expressar juízo de valor. Os comentários foram reservados aos artigos e às colunas assinadas". O reflexo dessa nova configuração é a queda do "jornalismo de opinião", fundado na noção de que o jornalista deve ter um mínimo de identidade para exercer alguma autoria. Atualmente, tendo que disputar com os departamentos de marketing e, no caso exemplar do Brasil, se curvar ao poder tentacular do Estado, além de estar atento à soberania do cliente e consumidor, o jornalista torna-se um elemento sem grande identidade no processo da informação. Abreu (2002) afirma que hoje os jornalistas perderam o lugar de porta-vozes da opinião pública, agora ocupado pelas pesquisas de mercado: "São elas que, através da consulta permanente ao público, revelam o que ele pensa, quais os seus gostos e preferências. São essas as informações que orientam a posição da mídia e dos políticos".

A velocidade, o marketing e a disputa pelo mercado da informação conformam o jornalista a um papel menor na comunicação. Autores discordam da queda acentuada de prestígio e espaço do profissional da comunicação e argumentam que os jornalistas estão sempre "dispostos a transferir para a determinação empresarial a 
responsabilidade pela seleção que se tornará visível" (Silva, 2002). A visibilidade maior do campo jornalístico (o jornalista como uma imagem, desapegado da opinião e da autoria na profissão) reforça a idéia do intelectual francês de que "os jornalistas sejam por vezes perigosos: nem sempre sendo muito cultos, surpreendem-se com coisas não muito surpreendentes e não se surpreendem com coisas espantosas" (Bourdieu, 1992).

O próprio Bourdieu avalia a dinâmica intrínseca que torna $o$ jornalismo o campo mais dependente:

O campo jornalistico tem uma particularidade: é muito mais dependente das forças externas que todos os outros campos de produção cultural, campo da matemática, campo da literatura, campo juridico, campo científico. Ele depende muito diretamente da demanda, está sujeito à sanção do mercado, do plebiscito, talvez mais ainda que o campo político. A alternativa do "puro" ou do "comercial" que se observa em todos os campos, ai se impõe com uma brutalidade particular e o peso do pólo comercial é ai particularmente forte: sem precedente em intensidade, é também se o compararmos sincronicamente, no presente, ao que ele é nos outros campos. Mas, além disso, não se encontra, no universo jornalístico, o equivalente do que se observa no universo científico, por exemplo, essa espécie de justiça imanente que faz com que aquele que transgride certas proibições se queime ou, ao contrário, que aquele que se conforma às regras do jogo atraia a estima de seus pares (manifestada, por exemplo, sob a forma de referências, de citações). No jornalismo onde estão as sanções, positivas ou negativas? (Bourdieu, 1999, p.78)

Observa-se que o teórico francês admite a extrema dependência do campo jornalístico. Em seguida, faz uma comparação que deve ser relativizada, pois no campo acadêmico, sabendo-se mais livre em comparação com o jornalístico, a "justiça imanente" não é 
aplicada da forma quase automática como afirma. Há, sim, no jornalismo as sanções tendo em vista a visibilidade do trabalho, a aferição diária do leitor, a vigilância dos proprietários das empresas e os índices de vendagem e audiência. Um jornalista para se manter bem na profissão, necessita adquirir credibilidade e está muito mais sujeito a avaliações e propenso a sanções do que os acadêmicos.

A particularidade do jornalismo brasileiro, atrelado ao modelo americano, contraria, em parte, as teses de Bourdieu. Mas ele tem razão, exceto na culpabilização personalizada do jornalista, quanto à homogeneização do campo jornalístico:

Se a informação fornecida por tal meio se torna uma informação-ônibus, sem aspereza, homogeneizada, vêemse os efeitos políticos e culturais que podem resultar disso. É uma lei que se conhece muito bem: quanto mais um órgão de imprensa ou um meio de expressão qualquer pretende atingir um público extenso, mais ele deve perder suas asperezas (Bourdieu, 1999, p.63).

Essa necessidade de alcançar um grande público, aliada a alta dependência do campo, encarcera o jornalista num processo que resulta na homogeneização das notícias e na aferição do trabalho pela "eficiência", como observa Alzira Abreu:

A maneira de trabalhar dos jornalistas é outro elemento que leva à homogeneidade: eles se lêem entre si, vêem os mesmos jornais na televisão à noite e cobrem os mesmos personagens politicos. Os jornalistas de Brasilia institucionalizaram a cobertura pelo que chamam de pool: alguns deles vão falar com um senador em evidência, outros vão ao ministro que está resolvendo alguma questão importante, e assim por diante. No fim, todos se encontram na sala de imprensa e uns checam as informações que obtiveram com os outros. Isso tende a uma "pasteurização brutal", de acordo com a opinião pública. (...) No novo jornalismo, submetido à pressão 
da concorrência - que afinal resume todos os outros tipos de pressão - os jornalistas também são submetidos a regras mais explicitas, destinadas a aumentar a eficiência do processo coletivo de trabalho. Seria esse, e não mais o "talento individual", o grande trunfo do jornalismo moderno" (Abreu, 2002, p. 36 e 37)

A profunda dependência do campo jornalístico é explicada em boa parte pela racionalização técnica que perpassa todas as profissões e a sociedade de uma maneira geral. Essa racionalização preconiza a homogeneização dos procedimentos de produção, a uniformização dos signos e a velocidade como atributos fundamentais para o jornalismo atual. O espaço para a opinião, todavia, fica restrito. O jornalismo de televisão é o exemplo mais bem acabado da subserviência a essa racionalização. Tanto que é praxe nas discussões e teorias sobre o jornalismo contrapor a figura do jornalista/intelectual de uma época em que ele detinha espaço para opinar ao jornalista da atualidade, em que a opinião é rara e compete somente a alguns profissionais do jornalismo impresso [a "opinião" no telejornlismo resvala para a noção de comentário]. Abreu (2002) aponta que "as redações contavam com jornalistas que não só analisavam e comentavam os acontecimentos políticos, como se viam no papel de indicar as alternativas para as mais variadas questões. Os jornalistas podiam ter e tinham opinião".

Atualmente, a opinião foi substituida, em alguns casos, pela força da "imagem" do profissional. Os jornalistas de televisão, pela alta visibilidade, acesso imediato ao poder e comunicação rápida com o público, exibem um "carisma" que lhes possibilita um poder simbólico jamais visto na história do jornalismo. São poucos os que detêm esse poder. O primado da opinião foi substituído pela utilização da "imagem". Como o jornalista perdeu muito de sua identidade, a possibilidade de destacar-se se restringiu a usar a própria imagem e se deixar usar. O personagem de Doces poderes, Alex (Tuca Andrade), não quer se "vender" às campanhas milionárias da política. Seu esforço é no sentido de fazer uma "imagem".Ele é pragmático, tanto quanto os colegas que foram trabalhar no marketing político, 
porém intui que a carreira propicia um tipo de poder que não envolve somente dinheiro. Senra (1997, p. 28) sintetiza com acuidade essa mudança de foco:

O processo que levou o jornalista a uma maior autoexposição e à busca de um outro tipo de reconhecimento parece sugerir que o anonimato acabou criando, para $o$ profissional de imprensa dos anos 80, um certo mal-estar, uma perda de foco da sua antiga figura, que viria a ser compensada não mais pela afirmação de uma "identidade", mas antes pela necessidade de construir uma "imagem" capaz de destacá-lo da massa indiferenciada da redação (Senra, 1997, p.28)

Essa passagem da opinião para a imagem denota dois caminhos: o do pragmatismo - como no caso de Alex -, e o do oportunismo - como no caso de Bob, que construiu sua imagem (a carreira profissional) como diretor de telejornalismo (Sergio Mamberti). Há jornalistas que se utilizam dessa nova figuração simbólica para tirar proveito tanto monetário quanto de poder. É emblemático o diálogo entre Bia e Bob:

Bob: Sabe minha querida...cansei desta história de não sujar as mãos. Estou ficando velho...e, por incrivel que pareça a você, o Ronaldo [alusão a Fernando Collor de Melo] é um cara legal. Até porque não dá para acreditar no Luisinho [alusão a Luis Inácio Lula da Silva]. Não é uma questão de preconceito. Você sabe que eu não tenho. $O$ que o Ronaldo tem a seu favor é uma mentalidade de primeiro mundo, fora dos padrões que a gente está acostumado...

Bia: $\dot{E}$ um verdadeiro herói moderno...

Bob: Herói é um pouco forte...um galã talvez...Mas não é por aí. Os tempos são outros. As revoluções passaram e nós estamos aqui, você por acaso acha possivel assumir a sucursal aqui em Brasília em pleno periodo eleitoral $e$ ficar com as mãos limpas? Experimente... 
Bob é um oportunista irônico que a narrativa irá punir. Sai da direção da redação da televisão, se empenha na campanha, mas logo em seguida é descartado por não ser tão esperto quanto um profissional da publicidade que o submete e o desmoraliza, tachandoo de inapto para o trabalho. Em seguida, vê-se o exemplo do pragmatismo do jovem repórter:

Bia: E você? Por que não saiu para a campanha? Soube que teve uma oferta irrecusável?

Alex: É verdade, dava até para comprar um apartamento. Mas não pense que foi por algum discurso de jornalista independente. Foi só porque eu me acho melhor do que um vendedor de deputado. Quero fazer carreira na TV. Não aceitei por pretensão...

Esse personagem representa o pragmatismo que se mistura com a idéia de profissionalismo. A racionalização trouxe para o jornalista o estatuto de profissional. O termo profissional está ligado diretamente à noção de objetividade, usada tanto pelos pragmáticos quanto pelos oportunistas. É a senha para se safar dos compromissos com a ética e da responsabilidade com o leitor e o espectador.

Doces poderes realiza o diagnóstico das questões do campo jornalístico apresentadas até aqui. O filme concentra-se em pólos: $\mathrm{Bia}$, a jornalista que representa o jornalismo e o jornalista, e Chico, deputado, que representa a política e o político. Ao redor, circulam Alex (o pragmatismo jornalístico), os jornalistas "comprados" e desiludidos, e o marketing político que submete o campo jornalístico. O tom da narrativa intenta expor ao máximo as entranhas do jornalismo e sua sujeição ao marketing. Em volta de Bia, pendula o desalento, exposto nos depoimentos inseridos como peças de filme-documentário, o pragmatismo de Alex e Chico e a agilidade anti-ética dos políticos de direita.

Quando resolve deixar o eixo Rio-São e assumir a sucursal da TNT [alusão à TV Globo], Bia dá um salto na profissão, pois ela é exemplo do profissionalismo reinante no jornalismo. Ela aceita o novo posto como uma missão. Neste aspecto, renova a idéia do 
"jornalismo como missão" exemplificada por Marcelo de $O$ desafio (1965). A personagem recarrega o sentimento de que a profissão é antes uma missão, para além da imagem, poder ou dinheiro. Há o desígno de purificar o estado de coisas latente e, para isso, abandona os prêmios para abraçar uma causa: a verdade. Bob reitera os enormes problemas que terá de enfrentar na sucursal. A maioria dos jornalistas foi ganhar dinheiro no marketing político e não há espaço para a identidade do jornalista:

Bob: Acho que você está se iludindo. Aliás, você tem o dom de iludir e de se iludir mesmo sabendo quem é o dono da voz

Bia: Simplesmente achei que poderia interferir mais. $\mathrm{Na}$ realidade...sei que se a oposição ameaçar, tudo pode ir para o espaço...Mas mesmo esta hipótese é uma experiência interessante. É isto. Estou querendo botar a mão na massa.

Bia é também o exemplo da profissional que usa da objetividade. É uma mistura que, aos poucos, vai delinear as contradições da heroína, pois vê o jornalismo como missão e, ao mesmo tempo, utiliza-se dela. Desde o início, Bia oscila entre a profissional e a missão a cumprir. Tenta unir as duas versões num amalgama que não corresponde à realidade de seu tempo:

O jornalista hoje se vê como um profissional pragmático, por oposição ao passado, quando a profissão era mais "romântica". A oposição romantismo x profissionalismo parece indicar que até os anos 70 os jornalistas tinham um envolvimento político e ideológico mais claro, agiam em função de valores e utopias, coisa que atualmente não ocorreria mais. Hoje, com o fim da bipolaridade capitalismo-socialismo, com o fim das utopias, com a visão pragmática do mercado e a predominância do sistema neoliberal e suas conseqüencias, teria mudado a forma de o jornalista pensar os fatos e praticar quotidianamente sua profissão (Abreu, 2002, p.38). 
Há ressalvas ao raciocínio de Alzira Abreu. A noção de missão não abarca automaticamente a idéia de romantismo. Por romântico pode-se deduzir somente a idéia de ingenuidade, além de oficializar um caráter idealista da profissão. Em $O$ desafio, Marcelo vê o jornalismo como uma missão. Há equívocos na proposta de Saraceni, mas representa o contexto da época: a sintonia do campo jornalístico com a influência do jornalismo europeu. Em Doces poderes, esses conceitos misturados encaminham a narrativa para $o$ cadafalso. Chico chama-a carinhosamente de "inglesa romântica" por querer, na sua visão, fazer um jornalismo não mais possível. Ele, de esquerda, adotou o pragmatismo:

A gente inverteu a campanha e eles foram obrigados a jogar pesado. Tenho a certeza que a gente aumentou o nosso eleitorado. E isto é o que importa. O futuro não termina agora.

O movimento da narrativa é no sentido de enobrecer Bia com suas atitudes. Todos os personagens chancelam e reforçam seu empenho heróico: Chico é igualado a Alex no pragmatismo; os jornalistas que dão depoimentos melancólicos e oportunistas "endossam" a missão da heroína. Se o jornalismo está eticamente comprometido, comprovado pelos depoimentos "realistas", Bia é o eixo de recomposição individual contra as conspirações externas que danificam a profissão. Sua missão é estabelecer o exemplo regenerador. Daí a importância dos depoimentos que intercalam o espaço da ficção para enfatizar, em tom "realista", documental, o descalabro da profissão e indiretamente solidificar a posição heróica de Bia:

Quando eu era jovem, acreditava em deus no colégio de freira. Ia à missa todos os dias. Ai veio o movimento estudantil e descobri Marx. Bom, com a repressão - e no meio daquele horror - comecei a fazer análise...Freud, quem sabe? Depois de dez anos de divã comecei a jogar na loteria: não ganhei...e agora...Não deixa de ser a 
loteria dos tempos que correm: 20 mil dólares...balanço desagradável de uma vida? Ou de uma geração? Não, corta esta última frase. Virou dramalhão (Vera - jornalista da campanha de Ronaldo)

O depoimento dentro do espaço ficcional relata a trajetória da jornalista que passou por movimentos e atitudes próprias dos anos associados ao "jornalismo romântico". Era politizada, foi marxista, fez psicanálise e o mundo racionalizado a seduziu com o dinheiro. Vera representa o ultrapragmatismo profissional. Faz desdém da sua boa formação, que talvez tenha contribuído para ganhar ainda mais dinheiro na atualidade.

Os depoimentos vão reforçando as atitudes de Bia que, depois de assumir o posto de diretora da sucursal, anuncia a estratégia para cobrir a campanha eleitoral. Na seqüência em que está na redação com o grupo principal de editores, ela dialoga sobre a campanha e Alex faz uma brincadeira sobre a cor de Luisinho, candidato de esquerda:

Editor: (meio gaiato) - É bom ser o Chico [deputado que apóia Luisinho] na entrevista porque o pessoal anda dizendo que não dá mais para entrevistar o Luisinho, que ele anda ocupadissimo porque está lançando um filme...

Alex: É, parece que se chama tiro no escuro. Ele faz o escuro (todo mundo ri)

Bia: (cortando a risada geral) - Não achei graça nenhuma

Alex: (contemporizando) - Bia, não dá para ser politicamente correto o tempo todo e não dá também para fugir da questão racial.

Bia: (um pouco irritada) - Ninguém quer fugir. Mas minha orientação é de um tratamento igualitário para todas as campanhas. Bom, outra coisa, a gente tem de contratar algumas pessoas para poder substituir quem foi para campanha. 


\section{Alex: Ah, não vai ser fácil.}

A seqüência é rica para reforçar o ponto de vista da autora, o diagnóstico da profissão e dar mais um passo na consolidação da autoridade moral de Bia. O avesso do diagnóstico é a não problematização profunda dos temas do jornalismo. Dessa forma, a cineasta depõe contra sua sinopse, em que afirma que os problemas serão tratados sem maniqueísmos. As seqüências vão criando os pólos do bem e do mal. A cada cena a aposta de que o mundo exterior é corrompido, maldoso e cínico se concretiza. Há uma grande armação exterior contra o mundo particular da heroína. Fora do seu mundo particular, onde vigoram a ética e a verdade, não há saída, a não ser a intervenção com as armas de uma certa justiça.

Bia estabelece o "politicamente correto" para rechaçar o preconceito dos colegas. O mais importante, entretanto, é o anunciado instrumento democrático para corrigir todas as parlendas: a objetividade. O tratamento será igualitário. Ou seja, todos os lados serão ouvidos. Se Lúcio Flávio irrompe como um herói de feição melodramática ao estilo Conde de Monte Cristo, ${ }^{5} \mathrm{Bia}$ segue o mesmo caminho. ${ }^{6}$ Os maus estão a sua volta corrompendo a moral e os

5. No livro Tese e antítese, Candido (1971, p. 22), ao analisar o romance de Alexandre Dumas, observa a feição melodramática da obra, semelhante ao tom empregado em Doces poderes: "Para se elevar a altura semelhante, da qual é possivel manobrar livremente os sentimentos e os destinos, Monte Cristo parte de uma simplificação psicológica e de uma verificação sociológica". Isso significa que, em termos psicológicos, divide os homens entre bons e maus, e, sociologicamente, em virtude da necessidade de ascensão social, são seduzidos e manipulados facilmente. A heroína de Murat utiliza-se da ausência de preceitos morais para estabelecer sua pedagogia, mesmo que a cartilha seja parcial e esteja acomodada numa visāo de mundo simplificada.

6. Borelli (1996) faz alusão ao elogio de Umberto Eco ao romance de Alexandre Dumas. Ele o compara com a obra de Alain Fournier, Le grande Meaulnes, $\mathrm{e}$ afirma que apesar de mal escrito, o romance de Dumas é uma das grandes obras da literatura pela forma apaixonante de narrar e nutrir o imaginário coletivo. Não há dúvida da força extraordinária do melodrama. Sua capacidade de atualização o remete para vários caminhos e dois exemplos ilustram a variedade: a forma melodramática do cinema americano atual que une procedimentos do gênero e a força imagética proporcionada pela tecnologia, caso do filme Titanic, 
códigos, com ironias, chistes e até manobras políticas rasteiras. Todavia, a heroína não é manipulável e age com senso de justiça escudada na objetividade. As circunstâncias vão fortalecendo a personagem. Se o campo jornalístico e o campo político estão inflados de perjúrio, desolação e seres manipuláveis, Bia estabelece sua pedagogia com exemplos regeneradores. Essa pedagogia, como observa Ismail Xavier, estabelece a dualidade moral do certo e errado:

O melodrama formaliza um imaginário que busca sempre dar corpo à moral, torná-la visivel, quando esta parece ter perdido os seus alicerces. Provê a sociedade de uma pedagogia do certo e do errado que não exige uma explicação racional do mundo, confiando na intuição $e$ nos sentimentos "naturais" do individual na lida com dramas (Xavier, 1998, p. 8)

No arranjo da narrativa, a força do diagnóstico, através da sua trajetória moralizante, consolida-se a cada passo no sentido de pôr ordem no mundo. A cada depoimento seu mérito cresce, pois além de enquadrar os colegas no "politicamente correto", mostra sua arma democrática: a objetividade. Quem ousaria contra Bia, se ela é correta e pratica a equidade? Há também nos depoimentos dos jornalistas o maniqueísmo do bem e do mal. Ambos visam ao reforço da personagem principal. De um lado há Vera, a jornalista hipócrita, versada em Marx e Freud, que agudiza o pólo do mal; de outro, está Teresa, pólo do bem. A primeira afirma que o mundo mudou e acompanha essas mudanças sem problema algum de consciência. Teresa partilha de um sentimento ambíguo: adere ao esquema do

e os melodramas que renovam o gênero com inteligência e perspicácia. É o caso de Pedro Almodóvar e seus filmes (De salto alto, Fale com ela e Tudo sobre a sua mãe). Mas talvez a teoria psicanalítica possa trazer uma nova luz para a discussão das estruturas do melodrama. Khel (2000) analisa dois filmes ( $O$ piano e Dead Man) em que o ressentimento trancafia a personagem do primeiro filme num "processo de infantilização", abortando qualquer aceno libertário. No outro filme, o personagem enfrenta as adversidades, mas o enfoque não acolhe o ressentimento, próprio dos personagens melodramáticos. 
marketing político, mas se considera vítima do contexto. Xavier (1998) afirma que o fracasso no melodrama "resulta de uma conspiração exterior que isenta o sujeito de culpa e o transforma em vítima radical". Teresa é uma vítima da monetarização do jornalismo:

Teresa - Acho que não tem mais o que discutir. É um mercado como outro qualquer. E nesta crise, fica sendo a única saida... Achei que dava prá ser independente, viver de fazer roteiros, mas isto é uma ilusão. Pelo menos para mim que tenho dois para criar e o pai não dá um puto...sabe aquela história de comprar comida com cartão de crédito? Pedir emprestado a Pai e Mãe e não saber como fazer para pagar o cartão no próximo mês? Pois é...

Em seguida, a narrativa volta para Vera para, no contraponto, municiar ainda mais a personagem principal. Vera está editando uma propaganda do candidato da direita, Ronaldo. Nas imagens aparecem membros da esquerda, em oposição ao candidato, sendo espancados. Ela edita o material, ultrapassa o universo diegético do filme e olha direto para a câmara:

Vera - Isto que vocês viram não aconteceu, sabiam? Como só a gente e a TNA tem o material [emissora onde Bia trabalha], elimina-se a realidade rapidinho. Provavelmente hoje à noite estas fitas já terão ido para o beleléu e estas imagens vão se tornar produto único da fantasia e do delírio da oposição... a gente já viu esta história um monte de vezes...mas toda vez é meio esquisito. Parece a primeira, tá barato né? Eu devia ter pedido pelo menos o dobro...

Teresa confronta o discurso de Vera. Sua indignação é parca, sem consistência, a não ser o de reiterar o papel de vítima. Apela para estabelecer uma oposição entre cinismo e objetividade, reforçando, também, a trajetória de Bia: 
Tereza - Me sinto em plena lei seca com Al Capone me pagando. Meu chefe diz que é um prurido bobo, um moralismo pequeno-burguês, que todo mundo trabalha com caixa 2, que assim pelo menos é tudo às claras e a gente não tem que pagar imposto. Tento me convencer que não é cinismo, é objetividade...Mas não consigo deixar de fazer as contas. Quanto de dinheiro clandestino não está rolando para fazer a campanha pelo país afora?

Objetividade para Teresa é o oposto de hipocrisia. Significa dizer que ser objetivo é ser profissional. Entretanto, a profissionalização do jornalismo, segundo Daniel Hallin (apud, Moretzsohn, 2002, p. 104), trouxe conseqüências e não pode ser encarada de forma acrítica. A profissionalização não trouxe dividendos nem para o jornalismo e sequer para o jornalista, pois é uma conseqüência do processo de racionalização:

Constitui parte de uma tendência geral de distanciamento da política partidária como base da vida pública e de aproximação de idéias de racionalidade administrativa $e$ de especialização neutra. Do jornalista se pressupunha que servisse ao público como um todo e não a interesses particulares, fossem eles as causas partidárias que os jornalistas tinham defendido no século $X X$ ou os tacanhos interesses comerciais de patrocinadores e proprietários. $A$ ideologia do serviço público era ligada à noção de objetividade, a fé em que era possivel reportar os eventos de um ponto de vista apolítico e a-sectário, baseado em critérios de noticiabilidade".

Ela tem culpa por estar trabalhando e recebendo dinheiro ilícito. Se o jornalismo foi também absorvido pela racionalização, Teresa aponta para o conceito que procura adequar o jornalista ao profissionalismo. O conceito foi criado no sentido de abrigar a ética, mas seu contorno ideológico inverteu a realidade, pois a objetividade não realizou as intenções da teoria da responsabilidade social de 1947 
. Usada como apanágio pelas empresas, o conceito legou muito mais que prejuízos na realidade. Ironicamente, Morettzsohn (2002) diz que defender a objetividade e o "profissionalismo" seria uma forma de "reagir aos interesses comerciais que cada vez mais se impõem."

O filme reafirma a utilização ideológica da objetividade. Bia segue o caminho contrário de Guigui de Boca de ouro. A protagonista de Nelson Pereira e Nelson Rodrigues dribla a objetividade, desbancando o repórter Caveirinha. Lucia Murat pretende criticar o jornalismo como fizeram os dois Nelsons. As escolhas narrativas são semelhantes porque trabalham com a estrutura clássica de linguagem. Lúcia Murat, assim como Babenco, ao privilegiar a "estrutura da consolação", erige heróis para ensejar exemplos de boa conduta e elevação moral. Tanto Lúcio Flávio quanto Bia tem aparentemente seus valores derrotados. Bia usa da objetividade e empreende a trajetória do herói para salvar a verdade. Não consegue destituir o mal, os poderes, mas deixa Brasília com o exemplo moral e a missão cumprida: "Todo o conflito no melodrama vai estar pautado por este tipo de transposição de obstáculos para se chegar a bom termo. Se esses valores são derrotados, isto será atribuído a uma espécie de conspiração externa que resulta na condição de vitimização radical dos valores positivos" (Xavier, 1999). Bia é a vítima que leva consigo um diagnóstico capenga do jornalista. A narrativa vê o jornalista como que destinado a ser o salvador, o árbitro. Ao descartar a tradição do cinema de autor, que privilegia a opinião do cineasta e sua visão de mundo, Murat limita sua pretensão, ao realizar uma estrutura narrativa que desliza sobre a superficie das questões.

Em Doces poderes, o telejornalismo é aparentemente criticado. Há uma simplificação da discussão sobre o campo jornalístico: o filme derrapa ao compor Bia em tom heróico, abandonar as questões de fundo e mostrar como a objetividade jornalística pode ser usada também pela "esquerda". Ou seja, se o conceito é aproveitado pelas empresas por que não o seria pelos jornalistas bem intencionados? Bia vai para Brasília, luta pela objetividade - ouvir todos os lados -e, nos bastidores, apóia Luisinho. Mesmo defendendo o tratamento igualitário na elaboração da notícia ao se posicionar ao lado de um dos candidatos, Bia o faz em nome da verdade. É, pois, 
possível transpor a "democracia objetiva", mas somente se for em nome de uma causa justa, verdadeira - exatamente como fazem as empresas quando desejam defender seus interesses e o fazem também em nome de uma causa justificada.

Ao optar por uma narrativa simplificadora, Doces poderes afasta o vigor do cinema de autor, reforça ingenuamente o conceito de objetividade, em vez de criticá-lo, superficializa a discussão sobre a condição do jornalista a partir dos anos 90 , e confirma a submissão do cinema ao marketing e a publicidade.

\section{Bibliografia}

ABREU, Alzira Alves de. A modernização da imprensa (19702000). Rio de Janeiro: Jorge Zahar Editor, 2002.

BORELLI, Silvia Helena Simões. Ação, suspense, emoção. São Paulo: Fapesp/Educ, 1996

BOURDIEU, Pierre. O poder simbólico. Rio de Janeiro: Bertrand Brasil, 1989.

BOURDIEU, Pierre. Sobre a televisão. Rio de Janeiro: Jorge Zahar, 1997.

CANDIDO, Antonio. Tese e antitese. São Paulo: Editora Nacional, 1971.

CONTI, Mario Sergio. Notícias do planalto. São Paulo: Companhia das Letras, 1999.

DINES, Alberto. O papel do jornal. São Paulo: Summus, 1996.

GENRO FILHO, Adelmo. O segredo da pirâmide: para uma teoria marxista do jornalismo.

GUERRA, Josenildo. A objetividade no jornalismo. Salvador: Dissertação de Mestrado, Faculdade de Comunicação da UFB, 1998.

KEHL, Maria Rita. Sobre ética e psicanálise. São Paulo: Companhia das Letras, 2002.

LALANDE, André. Vocabulário técnico e crítico da filosofia. São Paulo: Martins Fontes. 
MORETZSOHN, Sylvia. Jornalismo em "tempo real". Rio de Janeiro: Revan, 2002

ORTIZ, Renato. Moderna tradição brasileira. São Paulo: Brasiliense, 1988.

SENRA, Stela. $O$ último jornalista. São Paulo: Estação Liberdade, 1997.

SILVA, Marconi Oliveira da. O mundo dos fatos e a estrutura da linguagem. Porto Alegre: Edipucrs, 1997.

XAVIER, Ismail. Melodrama ou a sedução da moral negociada. Novos Estudos. São Paulo: Cebrap, n. 57, julho de 2000. 